\title{
MANAJEMEN PESERTA DIDIK BERBASIS PESANTREN DALAM PEMBENTUKAN KARAKTER DI MADRASAH ALIYAH NURULHUDA PRINGSEWU TAHUN PELAJARAN 2016/2017
}

\author{
Melisa Agustrianti, Feri Wahyudi, Moh. Masrur \\ Jl. Raya Wonokriyo Gadingrejo Pringsewu \\ Email: stitpringsewu@gmail.com
}

\begin{abstract}
This study aims to describe: (1) Implementation of Pesantren Based Student Management in Character Formation, (2) Success of Character Building Through Pesantren Based Student Management, And (3) Supporting Factors And Impediments of Pesantren Based Student Management in Character Building in MA Nurul Huda Pringsewu.

The result of research shows that pesantren boarding school management in character formation in MA Nurul Huda Pringsewu use three strategy step, that is moral knowing, moral feeling, and moral action. And in its application using four management functions, namely; (2) Organizing: establishing an organizational structure with the Asatidz Council Pondok Pesantren Nurul Huda Pringsewu (3) Implementation: launches four programs, namely: (a) formal system, (b) non-formal system, (c) organizational system, (d) vocational system. (4) Supervision: direct supervision and through evaluation of Headmaster along with Nurse and Board of Asatidz Pondok Pesantren Nurul Huda Pringsewu.

The successful management of pesantren-based learners in the formation of these characters can be seen from the achievement of existing indicators in the field, that is, there are ten values of characters that are formed: religious, honest, tolerance, discipline, self-reliant, friendly / communicative, democratic and respectful. While supporting factors and inhibiting the management of pesantren-based learner in the formation of character in MA Nurul Huda Pringsewu, supporting factors ayaitu: (a) motivation kyai, ustadz / teacher, and students who support, (b) adequate learning media, (c) climate and the tradition of pesantren that supports, (d) the figuration of kyai and ustadz / teacher as concrete examples, (e) vocational programs with adequate media, and (f) intimate communication between institutions and society. The inhibiting factors include: (a) inadequate learning media care standards, (b) pesantren traditions with simplicity, (c) lack of critical culture, (d) uneven activity effectiveness, and (e) negative external cultures.
\end{abstract}

\begin{abstract}
Abstrak
Penelitian ini bertujuan untuk mendeskripsikan: (1) Penerapan Manajemen Peserta Didik Berbasis Pesantren Dalam Pembentukan Karakter, (2) Keberhasilan Pembentukan Karakter Melalui Manajemen Peserta Didik Berbasis Pesantren, Dan (3) Faktor Pendukung Dan Penghambat Manajemen Peserta Didik Berbasis Pesantren Dalam Pembentukan Karakter di MA Nurul Huda Pringsewu.

Hasil penelitian menunjukkan bahwa, manajemen pesertadidik berbasis pesantren dalam pembentukan karakter di MA Nurul Huda Pringsewu menggunakan tiga langkah strategi, yaitu moral knowing, moral feeling, dan moral action. Dan dalam aplikasinya menggunakan empat fungsi manajemen, yaitu; (1) Perencanaan: (a) menentukan nilai-nilai karakter yang diprioritaskan, (b) melakukan sosialisasi, (c) mempersiapkan program harian, dan (d) melaksanakan pembiasaan dalam perilaku keseharian.(2) Pengorganisasian: membentuk struktur organisasi dengan Dewan Asatidz Pondok Pesantren Nurul Huda Pringsewu.(3) Pelaksanaan: mencanangkan empat program, yaitu: (a) sistem formal, (b) sistem non formal, (c) system organisasi, (d) system vokasional. (4) Pengawasan: pengawasan langsung dan melalui evaluasi Kepala Sekolah bersama Dengan Pengasuh Dan Dewan Asatidz Pondok Pesantren Nurul Huda Pringsewu.

Keberhasilan manajemen peserta didik berbasis pesantren dalam pembentukan karakter ini dapat dilihat dari ketercapaian indikator yang ada di lapangan, yaitu ada sepuluh nilai karakter yang terbentuk: religius, jujur, toleransi, disiplin, mandiri, bersahabat/komunikatif, gemar membaca, peduli lingkungan, kreatif, demokratis dan hormat/menghargai. Sedangkan factor pendukung dan penghambat manajemen peserta didik berbasis pesantren dalam pembentukan karakter di MA Nurul Huda Pringsewu, factor pendukungny ayaitu: (a) motivasi kyai, ustadz/guru, dan siswa yang menunjang, (b) media pembelajaran yang memadai, (c) iklim dan tradisi pesantren yang mendukung, (d) figurisasi kyai dan ustadz/guru sebagai teladan konkrit, (e) program vokasional dengan media yang memadai, dan (f) komunikasi yang akrab antara lembaga dengan masyarakat. Sedang factor penghambat meliputi:(a) standar perawatan media pembelajaran belum memadai, (b) tradisi pesantren dengan corak kesederhanaannya, (c) minimnya budaya kritis, (d) efektivitas kegiatan belum merata, dan (e) budaya negative dari luar.
\end{abstract}

Kata kunci: Manajemen PesertaDidik, Pesantren, Pembentukan Karakter 


\section{A. PENDAhuluan}

Sistem pendidikan pesantren di samping sejalan dengan sistem pendidikan yang dicanangkan pemerintah untuk dapat merespon perkembangan zaman, ada nilai plus yang melekat pada pesantren yaitu tetap mempertahankan kekhasan sebagai lembaga pendidikan Islam yang memiliki orientasi utama menanamkan nilai-nilai spiritual-keagamaan sebagai modal awal pembentukan akhlak dan moral generasi bangsa. Dengan begitu, implementasi manajemen peserta didik dengan basis pesantren akan membantu peserta didik dalam menyerap ilmu pengetahuan dan nilai-nilai moral sekaligus, karena tersedianya wadah berupa iklim pembelajaran yang memungkinkan mereka untuk mengembangkan kedua aspek tersebut.

Terkait dengan pentingnya manajemen peserta didik berbasis pesantren sebagai alternative dalam mencetak output pendidikan yang cerdas intelektualitas dan moralitasnya, salah satu lembaga pendidikan yang mengimplementasikan manajemen tersebut adalah Madrasah Aliyah Nurul Huda Pringsewu.

Dalam memberdayakan peserta didik, MA Nurul Huda Pringsewu berusaha memacu perkembangan intelektual (akal), jasmani, dan rohani peserta didik dengan mengadopsi sebagian sistem pendidikan formal dari pemerintah. Namun dalam aplikasi sistem pendidikannya tetap dalam bingkai nilai-nilai budaya dan tradisi pesantren sebagai bentuk upaya konkrit dalam menanamkan nilai akhlak dan moral sehingga dapat mencetak lulusan-lulusan yang cerdas dan berkarakter.

Manajemen Peserta Didik di MA Nurul Huda Pringsewu secara umum juga sejalan dengan teori manajemen pesertadidik yang dikembangkan para pakar manajemenilmiah. Namun,ada sisi menarik dari pelaksanaan manajemen peserta didik yang ada di MA Nurul Huda Pringsewu, yaitu hampir semua langkah-langkah dalammanajemen peserta didik selalu dalam bingkai sistem pendidikanpesantrenyang syarat akan nilai-nilai keagamaan serta tradisi-tradisi pesantren yangmerupakan kebiasaan sehari-hari yang menjadikan pesantren berbeda denganlembaga pendidikan lainnya.

Menurut Knezevich seperti yang dikutip Ali Imron mengemukakan:

"Manajemen peserta didik atau pupil personnel administration adalah suatu layanan yang memusatkan perhatian atau pengaturan, pengawasan dan layanan sisiwa dikelas dan diluar kelas seperti: pengenalan, pendaftaran, layanan individu seperti pengembanagan seluruh kemampuan, minat, kebutuhan sampai ia matang di sekolah."

Sedang menurut E. Mulyasa bahwa Manajemen peserta didik adalahpenataan dan pengaturan terhadap kegiatan yang berkaitan dengan peserta didik mulai dari masuk sampai dengan mereka lulus dari sekolah.

Dengan demikian dapat dijelaskan Manajemen Peserta didik adalah sebuah layanan yang memusatkan semua perhatian pada pengaturan, pengawasan, dan layanan individual seperti pengembanagan seluruh kemampuan, minat, kebutuhan sampai mereka matang mendapatkan proses pendidikan di sekolah.

Kemudian pola kehiduan pondok pesantren dan pendidikan yang berada dibawah pengelolaannya termanifestasikan dalam istilah "panca jiwa" dimana didalamnya memuat "lima jiwa" yang harus diwujudkan dalam proses pendidikan dan pembinaan karakter peserta didik. Kelima jiwa tersebut adalah jiwa keikhlasan, jiwa kesederhanaan, jiwa kemandirian, jiwa ukhuwah islamiyah dan jiwa kebebasan yang bertanggung jawab.

Mukti Ali sebagaimana dikutip oleh Abd. Halim Soebahar menjelaskan : "Tata pengelolaan peserta didik dengan basis pesantren paling tidak harus memiliki ciri-ciri: Pertama, adanya keakraban yang terjalin antara peserta didik dengan Kyai dan Mu'allim. Kedua, dalam proses belajar mengajar muncul ketundukan peserta didik pada kyai. Ketiga, gaya hidup sederhana. Keempat, sikap kemandirian yang kuat. Kelima, jiwa tolong menolong. Keenam, disiplin tinggi. Ketujuh, berani menderita untuk mencapai tujuan (tirakat).",

Dengan demikian dapat dijelaskan, bahwa yang dikehendaki dengan manajemen peserta didik berbasis pesantren adalahsistem pembinaan dan pengelolaan peserta didik yang dalam setiap prosesnya selalu dalam bingkai "lima jiwa"pesantren yang termanifestasi dalam bentuk budaya dan tradisi pesantren yang merupakan warna atau corak kehidupan sehari-hari di pesantren. Lembaga pendidikan formal di bawah naungan pesantrenyang merupakan pengembangan pesantren dalam melakukan kegiatan di upayakan selalu dalam iklim pembentukan sikap yang mengacu pada jiwa keikhlasan, jiwa kesederhanaan, jiwa kemandirian, jiwa ukhuwah islamiyah dan jiwa kebebasan yang bertanggung jawab.

Sedangkan Karakter yang dipahami sebagai sebuah sifat utama yang terukir, baik pikiran, sikap, prilaku dan tindakan, yang melekat dan menyatu kuat pada diri seseorang yang membedakanya dengan orang lain bukanlah sesuatu yang terbentuk dengan sendirinya. Ada empat faktor yang berpengaruh dalam pembentukan karakter seseorang yaitu: faktor hereditas, faktor lingkungan, faktor kebebasan manusia dalam menentukan karakter dan nasibnya, dan faktor hidayah Tuhan.

Dari penjelasan tersebut dapat dijelaskan, bahwa karakter adalah sesuatu yang bisa dibentuk sejak usia dini serta membutuhkan proses atau 
tahapan dalam pembentukanya. Menurut Zubaedi, proses pembentukan karakter terbagi menjadi empat tahapan: pertama, pada usia dini disebut dengan tahap pembentukan karakter. Kedua, pada usia remaja disebut dengan tahap pengembangan. Ketiga, pada usia dewasa, disebut tahap pemantapan. Keempat, pada usia tua disebut dengan tahap pembijaksanaan. Dan pengembangan dalam setiap tahapan tersebut harus melalui tiga tahapan yaitu knowing (pengetahuan), acting (pelaksanaan) dan menuju kebiasaan (habit).

Sementara Maragustam Mengemukakan, untuk menanamkan pilar-pilar atau nilai-nilai karakter seseorang sehingga membentuk karakter diperlukan "enam rukun" pendidikan karakter yang dilakukan secara utuh dan terus menerus. Keenam rukun tersebut yaitu; Pertama, habituasi (pembiasaan) dan pembudayaan yang baik. Kedua, membelajarkan hal-hal yang baik (moral knowing). Ketiga, moral feeling loving (merasakan dan mencintai yng baik). Keempat, moral acting (tindakan yang baik). Kelima, keteladanan (moral model) dari lingkungan sekitar. Keenam, tobat (kembali) keada Allah setelah melakukan kesalahan.

Dengan demikian dapat dikatakan karakter bukan hanya sebatas pengetahuan. Seseorang yang memiliki pengetahuan tentang kebaikan belum tentu ia mampu bertindak sesuai dengan pengetahuanya itu karna tidak terlatih untuk melakuakan kebaikan tersebut. Karena untuk membentuk karakter yang kuat dibutuhkan tahapan yang harus dilakukan secara holistik.

Berdasarkan hasil observasi ditempat bahwa manajemen peserta didik di MA Nurul Huda Pringsewu dapat dikatakan masih belum maksimal ataumasih kurang terutama dalamkebutuhan peserta didikbelum terpenuhi dengan baik. Dan keaktifan dalam kehadiran siswa juga masih sangat kurang. Akan tetapidapat dikatakan bahwa secara umum karakter siswa di MA Nurul Huda Pringsewu tergolong cukup baik.

Dari uraian tersebut, maka asumsi dasar yang penulis ambil adalah apabila hubungan diterapkanya manajemen peserta didik berbasis pesantren secara konsisten dapat membentuk karakter siswa.

Dari latar belakang tersebut, maka penelititerdorong untuk mengkaji tentang manajemen peserta didik yang dapat menyediakanwadahdan menciptakan iklimbagi peserta didik untuk berkembang secarautuhdalam setiap potensi dalam diri mereka(akal, jasmani, dan rohani) dengan judul:

\section{B. Tujuan}

Tujuan dilakukannya penelitian ini, guna untuk meneliti tentangManajemen Peserta Didik Berbasis Pesantren yang digunakan sebagai sarana dalam Pembentukan Karakter siswa. Penelitian ini bertujuan sebagai berikut:Untuk mendeskripsikan
Manajemen Peserta Didik Berbasis Pesantren Di MANurul Huda Pringsewu, Untuk mengetahui efektifitas pembentukan karakter melalui Manajemen Peserta Didik Berbasis Pesantren di MA Nurul Huda Pringsewu, Untuk mengetahui faktor-faktor apa saja yang menjadi pendukung dan penghambat Manajemen Peserta Didik Berbasis Pesantren Dalam Pembentukan Karakter di MA Nurul Huda Pringsewu.

\section{Metode}

Jenis penelitian yang digunakan peneliti adalah penelitiankualitatif, yaitu penelitian yang dilakukanpada kondisi yang alamiah sampel yang di gunakan adalah Tehnik probability Sampling yaitu Simple Random Sampling, dimana pengambilan anggota sampel itu dari populasi yang di lakukan secara acak. teknik pengumpulan data menggunakan Observasi, Interview (wawancara), dan Dokumentasi.

\section{Pembahasan}

Berdasarkan hasil penelitian melalui observasi, interview dan dokumentasi, maka penulis dapat mengumpulkan data-data dari objek penelitian dan kemudian akan penulis bahas dalam penelitian.

\section{a. Manajemen Peserta Didik Berbasis Pesantren Dalam Pembentukan Karakter Di MA Nurul Huda Pringsewu}

Seperti yang telah dipaparkan oleh kepala sekolah Ibu Asna Ghoni Ma'rifah, SE.

“ MadrasahAliyah Nurul Huda Pringsewu merupakan madrasah yang berbasis pesantren, kegiatanya adalah seperti tadarus live, sholat duha berjama'ah, hafalan Juz 'Amma dan surat-surat penting, hafalan kitab, pengajian, sholawatan, tahlilan dll.Agar semua itu dapat terlaksana sesuai harapan kami, kami disini menggunakan tiga strategi pendidikan karakter yaitu 1) Moral Knowing, 2) Moral Feelingdan3) Moral Action. Akan tetapi dalam pengaplikasianya kami menggunakan empat fungsi manajemen yaitu perencanaan, pengorganisasian, pelaksanaan dan pengawasan."

Dari wawancara diatas dapat diambil penjelasan bahwa Manajemen Peserta Didik Berbasis Pesantren Dalam Pembentukan Karakterdi MA Nurul Huda Pringsewu dengan menggunakan sistem pondok pesantren atau berbasis pesantren, sehingga diharapkan bisa menghasilkan output yang agamis yang memiliki nilai-nilai spiritualkeagamaan yang tinggi serta berkarakter dan berakhlak mulia, Kegiatanya berupa tadarus live, sholat duha berjama'ah, hafalan Juz 'Amma dan surat-surat penting, hafalan kitab, pengajian, sholawatan, tahlilan dan peneliti juga melihat bahwa terdapat kegiatan ekstrakurikuler yang umumnya ada dipesantren seperti Qiro'ah, kaligrafi, hadroh, da'i dll. 
Seperti dalam jurnal Purwanti(2017) mengatakan bahwa Dalam pendidikan karakter sangat penting dikembangkan nilai - nilai etika seperti kepedulian, kejujuran, keadilan, tanggung jawab, dan rasa hormat terhadap diri dan orang lain bersama dengan nilai - nilai kinerja pendukungnya seperti ketekunan, etos kerja yang tinggi, kerja keras, dan kegigihan sebagai basis karakter yang baik. Sekolah harus berkomitmen untuk mengembangkan karakter siswa berdasarkan nilai- nilai dimaksud, mendefinisikan dalam bentuk perilaku yang dapat diamati dalam kehidupan sekolah sehari - hari, sekolah harus mencontohkan nilai - nilai tersebut, mengkaji, mendiskusikan, dan menggunakannya sebagai dasar dalam hubungan antar manusia, serta mengapresiasi manifestasi nilai- nilai tersebut di sekolah dan masyarakat.

Untuk mewujudkanya sesuai dengan apa yang dikatakan oleh kepala sekolah dalam wawancara bahwa MA Nurul Huda Pringsewu menggunakan Tiga strategi yaitu 1) Moral Knowingdimana siswa diharapkan mampu untuk membedakan antara akhlak mulia dan akhlak tercela, 2) Moral Felling yaitu siswa diharapkan mampu menilaidirinya sendiri (muhasabah), serta membiasakan bersikap baik, dan bersikap empati kepada siapapunDan 3)Moral Actionyaitu siswa diharapkan mampu mempraktikkan nilai-nilai akhlak mulia itu dalam perilakunya sehari-hari, yang dalam pengaplikasianya menggunakan empat fungsi manajemen yaitu: perencanaan, pengorganisasian, pelaksanaan dan pengawasan.

1. Perencanaan (Planning) Manajemen Peserta Didik Berbasis Pesantren Dalam Pembentukan Karakterdi MA Nurul Huda Pringsewu Seperti yang telah di paparkan oleh kepala sekolah Ibu Asna Ghoni Ma'rifah, SE“ Perencanaanyang kami buat adalah pertama dengan menentukan nilai-nilai karakter yang kami perioritaskan, kedua dengan melakukan sosialisasi, ketiga yang kami lakukan adalah mempersiapkan program harian yang terakhir adalah dengan melaksanakan pembiasaan dalam prilaku keseharian."

Dari wawancara diatas dapat diambil penjelasan bahwa perencanaan (Planning) manajemen peserta didik berbasis pesantren di MA Nurul Huda Pringsewu sangat baik sekali, diantaranya melalui empat cara yang dapat peneliti jelaskan dengan lengkap dan tentunya bersumber dari ibu kepala sekolah MA Nurul Huda Pringsewu yaitu, (a) menentukan nilai-nilai karakter yang diprioritaskandiantaranya adalah religius, jujur, toleransi, disiplin, mandiri, bersahabat/komunikatif, gemar membaca, peduli lingkungan, kreatif, demokratis dan hormat/menghargai,(b) melakukan sosialisasi yaitu para guru mensosialisasikan tentang pentingnya karakter bangsa ini untuk dibentuk sebaik mungkin dan berlandaskan agama, melihat masalah karakter dan moral anak bangsa sekarang ini mengalami kemerosotan yang sangat memprihatinkan, maka MA Nurul Huda Pringsewu berusaha keras untuk menanamkan nilai karakter yang baik terhadap peserta didik (c) mempersiapkan program harian, dalam hal ini peneliti melihat bahwa peserta didik melakukan kegiatan seperti tadarus live, sholat duha bersama, sholat duhur bersama, berdo'a sebelum dan sesudah melaksanakan pelajaran, serta dianjurkan untuk puasa sunah senin-kamis dll, (d) melaksanakan pembiasaan dalam perilaku keseharian, dimana siswa dapat melakukan semua aktivitas tersebut tidak hanya disekolah saja akan tetapi pada keseharianya.

2. Pengorganisasian

(Organizing)

Manajemen Peserta Didik Berbasis Pesantren Dalam Pembentukan Karakterdi MA Nurul Huda Pringsewu Seperti yang telah di paparkan oleh kepala sekolah Ibu Asna Ghoni Ma'rifah, SE

"Dalam Pengorganisasian yang kami lakukan adalah membentuk Struktur Organisasi dengan Dewan Asatidz Pondok Pesantren Nurul Huda Pringsewu yang tak lain adalah beberapa guru-guru yang ada disekolah kami, sehingga dapat mudah untuk kami dalam pembagian tugas, dan melakukan koordinasi."

Dari wawancara diatas dapat diambil penjelasan bahwa pengorganisasian manajemen peserta didik berbasis pesantren di MA Nurul Huda Pringsewu tergolong sangat mudah dilakukan, ini terbukti dari pembentukan struktur organisasi yang anggotanya berasal dari dewan asatidz yayasan pondok pesantren Nurul Huda Pringsewu sendiri sehingga memudahkan dalam menjalankan tugas masing-masing dan dalam hal ini peneliti ikut serta didalamnya.

3. Pelaksanaan (Actuating) Manajemen Peserta Didik Berbasis Pesantren Dalam Pembentukan Karakterdi MA Nurul Huda Pringsewu Seperti yang telah di paparkan oleh kepala sekolah Ibu Asna Ghoni Ma'rifah, SE“ Dalam pelaksanaannya kami menggunakan empat sistem, yaitu: a) sistem formal, b) sistem non formal c) sistem Organisasi, d) sistem vokasional, dalam penyajianya kami menggunakan beberapa strategi yaitu 1) Moral Knowing, 2) Moral Feeling, dan 3) Moral Action, dengan ini diharapkan semoga karakter siswa dapat tebentuk dalam rohani dan jasmaninya."

Dari wawancara diatas dapat diambil penjelasan bahwa dalam pelaksanaan Manajemen Peserta Didik Berbasis Pesantren Dalam Pembentukan Karakterdi MA Nurul Huda Pringsewu menggunakan empat sistem yaitu sistem formal,yaitu kegiatan manajemen peserta didik dimulai dari analisis kebutuhan peserta didik, rekrutmen peserta didik, seleksi peserta didik hingga pada kelulusan dan alumni, selanjutnya 
adalah sistem non formal, yaitu kegiatan atau pembelajaran berbasis pesantren, seperti hafalan Juz 'Amma, surat-surat penting seperti AlWaqi'ah, Ar-Rohman, Yasin, Al-Mulk dan hafalan kitab, hadrohan, sholawatan, tahlilan dll, kemudian sistem organisasi, yaitu organisasi yang dibentuk disekolah baik dalam struktur organisasi sekolah, OSIS/ROHIS dan sistem vokasionalyaitu kegiatan keterampilan yang ada dalam kegiatan ekstrakurikuler diantaranya adalah Khottil Atau Kaligrafi, Qiro'ah, Da'i, Nasyid, Hadroh, Pramuka, Madding, PASKIBRAKA, PIK-KRR, Matematika, MKKT Nahwu-Sharaf, Akutansi, KIR, Volly Ball, English Club Dan Arabic Club.

Dalam penyajianya MA Nurul Huda Pringsewu menggunakan beberapa strategi yaitu1) Moral Knowing, disiniguru mengenalkan pada penguasaan pengetahuan tentang nilai-nilai, sehingga peserta didik mampu untuk membedakan antara akhlak mulia dan akhlak tercela serta nilainilai universal lainnya 2) Moral Feeling,strategi ini adalahuntuk menumbuhkan dan menguatkanrasa cinta dan rasa butuh terhadap nilai-nilai akhlak mulia (emosi). Disini guru harus memperhatikan emosional setiap peserta didik, dengan memberikan cerita tentang kisah-kisah yang menyentuh hati, sehingga kami berharap agar siswa mampu menilaidirinya sendiri (muhasabah), serta membiasakan bersikap baik, dan bersikap empati kepada siapapun, 3) Moral Action, disini dapat dikatakan hasil dari tahap 1 dan tahap 2, yaitu perbuatan/tindakan pesera didik apakah mereka sudah mempraktikan prilaku baikatau akhlak mulia dalam keseharianya, disini guru harus memperhatikan kompetensi, keinginan dan kebiasaan setiap peserta didik dan guru beserta warga sekolah wajib menjadi teladan dari peserta didik dan mencontohkan perilaku yang baik.

4. Pengawasan (Controlling) Manajemen Peserta Didik Berbasis Pesantren Dalam Pembentukan Karakterdi MA Nurul Huda Pringsewu Seperti yang telah di paparkan oleh kepala sekolah Ibu Asna Ghoni Ma'rifah, SE “ Dalam pengawasannya dilakukan secara langsung saja dan dengan melalui pengawasan saya sendiri sebagai kepala sekolah bersama pengasuh dan dewan asatidz Pondok Pesantren Nurul Huda Pringsewu."

Dari wawancara diatas dapat diambil penjelasan bahwa pengawasan yang dilakukan adalah pengawasan secara langsung oleh kepala sekolah bersama dengan pengasuh dan dewan asatidz pondok pesantren nurul huda pringsewu

\section{b. Kegiatan Manajemen Peserta Didik Berbasis Pesantren Dalam Pembentukan KarakterDi MA Nurul Huda Pringsewu}

Seperti yang telah di paparkan olehWaka KesiswaanIbu Siti Zubaidah, SE,

1) Analisis Kebutuhan Peserta didik

“ Disini kami melakukan rapat dahulu dan merencanakan jumlah peserta didik yang akan kami terima dengan pertimbangan daya tampung kelas/ jumlah kelas yang tersedia, Dan kamipun juga mempertimbangkan antara adanya murid dan guru. Kamipun juga menyusun program kegiatan kesiswaan yaitu..."

Dari wawancara diatas dapat diambil penjelasan bahwa analisis kebutuhan peserta didik di MA Nurul Huda Pringsewu adalah dengan melakukan perencanaan terhadap peserta didik yang akan diterima dengan pertimbangan jumlah kelas yang tersedia,akan tetapi kenyataanya selama ini siswa yang masuk itu masih kurang atau bahkan cukup dari batas maksimal yang telah ditentukan, sehingga MA Nurul Huda Pringsewu belum pernah mengadakan penolakan terhadap siswa baru. Selanjutnya MA Nurul Huda Pringsewujuga mempertimbangkan rasio antara guru dan murid, kemudian menyusun program kegiatan kesiswaan sesuai bakat dan minat peserta didik, sarana dan prasarana yang ada, anggaran yang cukup, dan tenaga kependidikan yang tersedia.

2) Rekruitmen Peserta Didik

“ Mengenai perekrutan siswa baru kami membentuk Panitia Penerimaan Siswa Baru (PSB) selain itu kami juga merumuskan syarat-syarat calon peserta didik, kami juga melakukan penyebaran informasi menggunakan brosur, banner, spanduk yang di sebar dan menggunakan website, radio selain itu juga ada tim sosialisasi yang mengunjungi SMP-SMP ataupun Mts-Mts untuk memperkenalkan sekolah kami kepada mereka yang berminat untuk bersekolah di Madrasah ini yang terdiri dari guru dan peserta didik, kami juga menyediakan formulir pendaftaran."

Dari wawancara diatas dapat diambil penjelasan bahwa rekrutmen peserta didik dilakukan dengan a) membentuk Panitia Penerimaan Siswa Baru (PSB) yang dibentuk secara khusus meliputi: ketua, wakil ketua, penanggung jawab, humas, bendahara dan sekertaris serta PU (pembantu umum) yang terdiri dari wakil kepala sekolah, waka kesiswaan, guruguru dan staff tata usaha,b) menyediakan formulir pendaftaran, yang berisi tentang data diri peserta didik, data madrasah/sekolah asal dan data orang tua/wali, dan pelaksanaan pendaftarannya sesuai dengan jadwal yang telah ditetapkan c) merumuskan syarat-syarat calon peserta didik, d) penyebaran informasi menggunakan brosur, banner, spanduk yang di sebar dan menggunakan website, radio dan e) melakukan sosialisasi kesekolah-sekolah, yang dilakukan oleh guru dan beberapa peserta didik.

3) Seleksi Peserta Didik

"Untuk seleksi kami menggunakan tes tertulis dengan menjawab soal-soal yang berbasis umum seperti: IPA, IPS, matematika, bahasa indonesia dan bahasa inggris. Selain itu kami 
melakukan tes baca Al-Qur'an surat wajibnya AlWaqiah dan yang terakhir tes menulis surat alfatihah. Karena kita berbasis ponpes jadi berbau Islami, selain itu tes ini juga berfungsi untuk memilih kejuruan anak nanti ketika kelas X1"

Dari wawancara diatas dapat diambil penjelasan bahwa dalam melakukan seleksi terhadap peserta didik menggunakan tes tertulisdengan menjawab soal-soal yang berbasis umum seperti: IPA, IPS, matematika, bahasa indonesia dan bahasa inggris, selanjutnya tes baca Al-Qur'an dan menulis arab.

4) Orientasi Peserta Didik

" Untuk orientasi siswa terhadap situasi dan kondisi sekolah, kami sepenuhnya menyerahkan kepada segenap panitia dari beberapa guru dan OSIS untuk menjalankan kegiatan tersebut, Alhamdulillah selama ini selalu berjalan dengan lancar dan dari setiap periode ke periode, tentunya kegiatan yang dilakukan tidak terlepas dari pengawasan serta ala pesantren."

Dari wawancara diatas dapat diambil penjelasan bahwa masa orientasi siswa (MOS) dilakukan dengan baik serta tidak terlepas dari pengawasan guru-guru dan peneliti melihat semua kegiatan dilakukan dengan ala pesantren seperti sholawatan bersama, hadrohan bersama, dan materi tentang kepesantrenan, terutama hak dan kewajiban peserta didik selama masih menempuh pendidikan di madrasah,juga ada penampilan-penampilan bakat yaitu qiro'at, tartil,kaligrafi, Pagar Nusa, Nasyid dll.

\section{5) Penempatan Peserta Didik}

“ Karena disini siswanya masih sedikit, kami masih mencampur antara laki-laki dan perempuan, baik yang seumuran atau tidak, baik yang cerdas dengan yang kurang, Akan tetapi kami melakukan pembagian kelas melihat dari nilai SKHU, dan hasil tes, jika nilai keagamaanya tinggi maka kami masukkan kekelas AGAMA, sementara madrasah kami menyediakan dua kategori kelas yaitu AGAMA dan IPS, untuk kelas X, XI dan XIImasing-masing 2 kelas, 1 kelas untuk AGAMA dan 1 kelas untuk IPS."

Dari wawancara diatas dapat diambil penjelasan bahwa MA Nurul Huda memiliki dua kategori/ jurusan kelas yaitu AGAMA dan IPS, dalam pembagian kelasnya dilakukan dengan melihat nilai SKHU dan hasil tes mereka, bagi yang nilai keagamaanya tinggi maka dimasukkan kekelas AGAMA, selebihnya di kelas IPS.

6) Pembinaan Dan Pengembangan Peserta Didik

“ Dalam pembinaan dan pengembangan peserta didik kami melakukan beberapa langkah yaitu pembinaan disiplin peserta didik kemudian kami juga mengadakan kegiatan ekstra kurikuler serta memberikan layanan khusus."

Dari wawancara diatas dapat diambil penjelasan bahwa pembinaan dan pengembangan peserta didik dilakukan dengan beberapa langkah yaitu pembinaan disiplin peserta didik,seperti membuatketentuan jam masuk yaitu 07.15 WIB dan jika peserta didik terlambat maka diberi hukuman, selain itu adanya ketentuan khusus dalam berpakaian wajib seragam, rapi, sopan terutama seragam yayasan, kemudian guru BK juga mengadakan razia terhadap cara berpakaian peserta didik serta penampilan peserta didik seperti rambut panjang bagi laki-laki, selain itu pada proses pembelajaran guru wajib memberikan teguran dan hukuman bagi siswa yang ribut dan tidak memperhatikan pelajaran,MA Nurul Huda juga mengadakan kegiatan ekstra kurikulersetiap 1 minggu sekali, diantaranya adalahKaligrafi, Qiro'ah, Da'i, Nasyid, Hadroh, Pramuka, Madding, PASKIBRAKA, PIK-KRR, Matematika, MKKT Nahwu-Sharaf, Akutansi, KIR, Volly Ball, English Club Dan Arabic Club dan menyediakan layanan khusus yang tersedia seperti bimbingan konseling, perpustakaan, UKS, Kantin dan lab komputer.

7) Pencatatan Dan Pelaporan Peserta Didik

" Dalam hal pencatatan dan pelaporan, peserta didik yang sudah diterima akan kami catat dalam buku induk peserta didik, daftar nama peserta didik kami masukkan dalam daftar presensi guna untuk mempermudah dalam mencatat kehadiran peserta didik dan memberikan penilaian, kemudian yang sudah tercatat akan dilaporkan ke pangkalan data oneline dan ada juga daftar catatan pribadi peserta didik."

Dari wawancara diatas dapat diambil penjelasan bahwa pencatatan peserta didik dilakukan dengan memasukan data peserta didik dalam buku induk peserta didik, selanjutnya buku daftar presensi, kemudian setiap guru membuat daftar nilai, dan mengenai pembagian lapor dilakukan dengan memberikan langsung kepada peserta didik dan wali, kemudian masalah pengaturan perpindahanpeserta didik dilakukan dengan mengecek sekolah yang akan dimasuki apakah benar-benar mau menerima atau tidak peserta didik yang akan pindah, kemudian menyelesaikan surar-surat yang diperlukan sebagai pengantar yang akan dibawa peserta didik ketika akan pindah kesekolah lain.

8) Kelulusan Dan Alumni

“ Mengenai kelulusan peserta didik kami, sudah dianggap lulus jika sudah memenuhi syaratsyarat kelululsan yaitu peserta didik dinyatakan telah menyelesaikan seluruh mata pelajaran, menyelesaikan administrasi, dan telah lulus Ujian Nasional, mengenai alumni kami tidak memiliki organisasi ikatan alumni akan tetapi alumni memiliki ikatan sendiri pada setiap angkatanya."

Dari wawancara diatas dapat diambil penjelasan bahwa peserta didik dianggap lulus jika sudah memenuhi syarat-syarat kelululsan yaitu peserta didik telah menyelesaikan seluruh mata pelajaran, menyelesaikan administrasi, dan telah 
lulus Ujian Nasional, dan juga seperti yang peneliti lihat dalam pengambilan ijazah peserta didik diberikan syarat yaitu setoran hafalan surat penting seperti Al-Waqi'ah, Ar-Rohman, Yasin dan AlMulk, mengenai alumni MA Nurul Huda Pringsewu tidak memiliki organisasi ikatan alumni akan tetapi ada ikatan alumni pada setiap angkatanya.

\section{c. Keberhasilan Pembentukan Karakter Melalui Manajemen Peserta Didik Berbasis Pesantren Di MA Nurul Huda Pringsewu}

Seperti yang telah di paparkan olehWaka Kesiswaan Ibu Siti Zubaidah, SE,

“ Alhamdulillah Keberhasilan Pembentukan Karakter Melalui Manajemen Peserta Didik Berbasis Pesantren Di MA Nurul Huda Pringsewu dapat saya katakan cukup maksimal atau berhasil, hal ini terlihat dari perilaku peserta didik yang sopan santun, menghormati guru dan nilai-nilai karakter yang kami perioritaskan dapat berhasil dimiliki oleh peserta didik kami yaitu religius, jujur, toleransi, disiplin, mandiri, bersahabat/komunikatif, gemar membaca, peduli lingkungan, kreatif, demokratis dan hormat/menghargai, harapan saya semoga Allah memberikan keberkahanya kepada kita semua."

Dari wawancara diatas dapat diambil penjelasan bahwa pembentukan karakter peserta didik melalui manajemen peserta didik berbasis pesantren dapat dikatakan cukup berhasil, hal ini terbukti dari tercapainya semua indikator atau nilai-nilai karakter yang diperioritaskan oleh madarasah tersebut yaitu religius, jujur, toleransi, disiplin, mandiri, bersahabat/komunikatif, gemar membaca, peduli lingkungan, kreatif demokratis dan hormat/menghargai.

Selain itu peneliti juga melakukan observasi mengenai hal ini, dalam hasil observasi yang peneliti lakukan bahwa hal tersebut memang benar terbukti, disini peneliti melakukan pengamatan secara langsung kegiatan peserta didik di mulai dari bangun tidur hingga tidur lagi, hal ini mudah untuk dilakukan karena peneliti juga tinggal bersama dengan peserta didik.

Hal yang pertama dikatakan oleh Waka Kesiswaan ibu Siti Zubaidah, SE bahwa peserta didik memiliki sifat religius hal ini terbukti dari perilaku peserta didik yang bangun pukul 02.30 lalu mandi dan melakukan sholat tahajud, membaca Al-Qur'an serta wirid hingga sampai waktu subuh dan tidak hanya itu peserta didik juga berpenampilan rapi, sopan, dan bersih juga terlihat kemanapun pergi selalu membawa Al-Qur'an dan buku miliknya, kemudian juga melakukan sholat duha baik disekolah maupun dipondok .

Sifat Jujur, hal ini terbukti dari prilaku peserta didik misalnya dalam pengambilan jatah makan, mereka tidak pernah mengambil lebih dari jatah yang telah diberikan walau tanpa pengawasan, selain itu peserta didik juga berani meminta maaf dan mengakui kesalahan yang telah diperbuat kepada pengasuh dengan jujur tanpa ada cerita tambahan. Dan juga Mengerjakan ujian tanpa mencontek buku atau teman.

Sifat Toleransi, hal ini terbukti dari walau di pondok/disekolah terdapat banyak teman yang berbeda baik dari suku, warna kulit, prestasi, pendapat maupun latar belakang keluarga mereka tetap saja dapat berteman dengan baik, bekerja sama, dan saling tolong menolong.

Sifat Disiplin, hal ini terbukti dari ketika akan masuk sekolah peserta didik sudah bersiap-siap mandi sebelum subuh agar tidak terlambat masuk sekolah, dan juga tidak ada santri yang tidak sholat berjamaah atau sholat dikamar sendiri, atau tidak mengaji karna dalam hal ini ada sanksi yang telah di tentukan bagi santri yang melanggar.Sifat Mandiri, hal ini terbukti dari tidak ada ketergantungan dengan orang lain dalam mengerjakan tugasnya/pekerjaanya, mencuci pakaian sendiri, dan dapat memilih keputusan yang tepat dan bijaksana dalam menyelesaikan masalahnya sendiri.

Sifat Bersahabat/komunikatif, hal ini terbukti dari perilaku peserta didik yang berteman dengan siapapun tanpa memandang perbedaan apapun diantara mereka, serta menjalin komunikasi yang baik kepada siapapun.

Sifat Gemar membaca, hal ini terbukti dari perilaku peserta didik yang lebih sering datang ke perpustakaan ketika ada jam kosong atau jam istirahat untuk membaca buku dibanding lebih banyak bermain, dan peserta didik juga tercatat sering maminjam buku diperpustakaan untuk dibaca dimana tempat yang mereka inginkan.

Sifat Peduli lingkungan, hal ini terbukti dari perilaku peserta didik yang dengan semangat saling membagi tugas piket antar kamar/kelasnya masingmasing, dan ketika melihat dimanapun yang terlihat kotor dengan senang hati mereka akan membersihakanya sendiri tanpa ada perintah, tanpa mengandalkan teman yang lain, serta tidak membuang sampah sembarangan.

Sifat Kreatif, dalam hal ini terbukti dari hasil karya yang telah dibuat oleh peserta didik/ santri dalam memenangkan beberapa lomba yaitu lomba daur ulang, mereka membuat banyak karya yang berbeda-beda dan menarik salah satunya adalah baju gaun yang terbuat dari Koran, terlihat bagus sekali, kaligrafi yang sangat indah, bahkan karya peserta didik/santri Nurul Huda Pringsewu menjadi kejuaraan nasional Indonesia yaitu film pendek yang berjudul Alif dan mendapat Juara III Nasional di Jakarta, dan masih banyak lagi.

Sifat Demokratis, hal ini terbukti dari perilaku peserta didik yang melakukan pemilihan kepemimpinan secara demokrasi baik disekolah maupun dipondok dan contoh kecilnya lagi adalah ketika kelasnya mendapatkan Juara dalam lomba maka hasil atau hadiah yang mereka dapatkan 
dapat dirasakan oleh semua peserta didik sekelasnya, mereka membagi rata hasilnya dengan senang hati.

Sifat Hormat/menghargai, hal ini terbukti dengan perilaku siswa yang saling menghormati kepada yang lebih tua darinya orang tua, guru dan dengan sesama teman. Serta adanya saling menghargai terhadap perbedaan pendapat maupun hal lainya yang dapat di selesaikan dengan baik, serta saling menghargai antar prestasi sesama teman.

\section{d. Faktor Pendukung Manajemen Peserta Didik Berbasis Pesantren Dalam Pembentukan Karakter Di MA Nurul Huda Pringsewu}

Seperti yang telah di paparkan olehWaka KesiswaanIbu Siti Zubaidah, SE,“ Menurut saya, yang menjadi faktor pendukungnya yang pertama adalah motivasi kyai, ustadz/guru dan siswa yang menunjang yang kedua adalah adanya media pembelajaran yang memadai, apabila media pembelajaran kurang memadai maka tidak akan berjalan dengan efektif, selanjutnya adalah dengan iklim dan tradisi pesantren yang mendukung, sehingga peserta didik dapat dengan mudah untuk beradaptasi, kemudian juga figurisasi kyai dan ustadz atau guru juga sangat penting sebagai teladan konkrit bagi peserta didik, terakhir adalah program vokasional (keterampilan) dengan media yang memadai serta komunikasi yang baik antara lembaga dan masyarakat."

Dari wawancara diatas dapat diambil penjelasan bahwa faktor pendukung manajemen peserta didik berbasis pesantren dalam pembentukan karakter di MA Nurul Huda Pringsewuadalah (a) motivasi kyai, ustadz/guru, dan siswa yang menunjang, , hal ini terbukti dikarenakan peserta didik MA Nurul Huda Pringsewuyang juga merupakan santri dan tinggal dipondok pesantren nurul huda, sehingga motivasi dari pak kyai, dan ustadz/guru sangat diperlukan, dan juga dengan adanya peserta didik yang menunjang, maka manajemen peserta didik akan terlaksana, (b) media pembelajaran yang memadai, (c) iklim dan tradisi pesantren yang mendukung, (d) figurisasi kyai dan ustadz/guru sebagai teladan konkrit, (e) program vokasional dengan media yang memadai (f) komunikasi yang baik dengan masyarakat.

\section{e. Faktor Penghambat Manajemen Peserta Didik Berbasis Pesantren Dalam Pembentukan Karakter Di MA Nurul Huda \\ Pringsewu}

Seperti yang telah di paparkan oleh Waka Kesiswaan Ibu Siti Zubaidah, SE, “ Kalau faktor penghambatnya, adalah masih kurangnyastandar perawatan media pembelajaran, kemudian tradisi pesantren dengan corakkesederhanaanya, minimnya budaya kritis juga menjadi faktor penghambat karena tidak ada ide-ide baru dan inovasi baru dalam pelaksanaanya, dan juga efektivitas kegiatan masih belum merata, dan budaya negatif dari luar pun berpengaruh terhadap kelancaran kegiatan."

Dari wawancara diatas dapat diambil penjelasan bahwa yang menjadi faktor penghambatnya adalah (a) standar perawatan media pembelajaran masih belum memadai, hal ini terbukti ketika akan menggunakanya sedang dalam keadaan rusak atau bahkan hilang sehingga kegiatan terhambat atau kurang efektif (b) tradisi pesantren dengan corak kesederhanaannya, (c) minimnya budaya kritis, (d) efektivitas kegiatan belum merata, hal ini disebabkan masih kurangnya kerja sama sekolah dengan pengurus pondok antar komplek yang memiliki peraturan dan jadwal yang berbeda-beda dan (e) budaya negatif dari luar, seperti adanya pengaruh teman dari luar yang tidak mukim di pondok.

\section{E. Penutup}

\section{1) Kesimpulan}

Dari hasil penelitian yang telah dilkakukan, maka dapat diambil beberapa Kesimpulan, yaitu:

1. Manajemen peserta didik berbasis pesantren dalam pembentukan karakter di MA Nurul Huda Pringsewu, menggunakan strategi moral knowing, moral feeling, dan moral action. Adapun ruang lingkupnya meliputi: analisis kebutuhan, rekrutmen, seleksi, orientasi, penempatan, pembinaan/pengembangan, pencatatan/pelaporan dan kelulusan/alumni. Serta dalam aplikasinya menggunakan empat fungsi manajemen yaitu:

a. Perencanaan (Planning) Cara yang dilakukan adalah dengan beberapa langkah: (a) menentukan nilai-nilai karakter yang diprioritaskan, (b) melakukan sosialisasi, (c) mempersiapkan program harian, dan (d) melaksanakan pembiasaan dalam perilaku keseharian.

b. Pengorganisasian (Organizing) Cara yang dilakukan adalah membentuk struktur organisasi dengan Dewan Asatidz Pondok Pesantren Nurul Huda Pringsewu.

c. Pelaksanaan (Actuating) Cara yang dilakukan adalah dengan menggunakan empat sistem yaitu sistem formal, sistem non formal, sistem organisasi dan sistem vokasional.

d. Pengawasan (Controlling) Pengawasan yang dilakukan adalah pengawasan secara langsung oleh Kepala Sekolah bersama Dengan Pengasuh Dan Dewan Asatidz Pondok Pesantren Nurul Huda Pringsewu

2. Keberhasilan Manajemen Peserta Didik Berbasis Pesantren dalam Pembentukan Karakter Di MA Nurul Huda Pringsewu adalah dilihat dari ketercapaian indikator yang ada di lapangan, yaitu ada sebelas nilai karakter yang terbentuk: religius, jujur, toleransi, disiplin, 
mandiri, bersahabat/komunikatif, gemar membaca, peduli lingkungan, kreatif, demokratis dan hormat/menghargai.

3. Faktor Pendukung dan Faktor Penghambat Manajemen Peserta Didik Berbasis Pesantren dalam Pembentukan Karakter Di MA Nurul Huda Pringsewu adalah sebagai barikut:

a. Faktor Pendukung meliputi:

1) Motivasi kyai, ustadz/guru, dan siswa yang menunjang pelaksanaan pembentukan karakter.

2) Media pembelajaran yang memadai dan menunjang keberlangsungan proses belajar mengajar.

3) Iklim dan tradisi pesantren yang mendukung

4) Figurisasi kyai dan ustadz/guru sebagai teladan konkrit,

5) Program vokasional dengan media yang memadai.

6) Komunikasi yang akrab antara lembaga dengan masyarakat,

b. Faktor Penghambat meliputi:

1) Standar perawatan media pembelajaran masih belum memadai

2) Tradisi pesantren dengan corak kesederhanaannya

3) Minimnya budaya kritis

4) Efektivitas kegiatan belum merata, dan

5) Budaya negatif dari luar.

\section{2) SARAN}

Saran-saran yang akan penulis ajukan tidak lain sekedar untuk memberikan masukan dengan harapan agar upaya pembentukan karakter di MA Nurul Huda Pringsewu dapat berjalan dengan optimal. Adapun saran-saran berikut penulis sampaikan kepada:

\section{Kepala MA Nurul Huda Pringsewu}

a. Hendaknya meningkatkan kembali komunikasi dengan pengasuh Pondok Nurul Huda sebagai induk dari MA Nurul Huda agar semuanya proaktif memberikan dukungan dan motivasi kepada pendidik dan kependidikan agar berkomitmen bersama dalam melaksanakan pengelolaan peserta didik berbasis pesantren sehingga dapat mencetak output yang baik dan pintar.

b. Hendaknya mengintegrasikan para pendidik dari rumpun agama dengan non agama, sehingga lebih terjalin komunikasi yang baik dan membangun kolaborasi dalam rangka menanamkan nilai-nilai karakter atau moral kepada peserta didik

\section{Pendidik}

a. Hendaknya pendidik mempertahankanuntuk selalu aktif terlibat dalam segala kegiatan yang berperan dalam penanaman nilai-nilai karakter peserta didik. b. Hendaknya mempertahankan untuk selalu memberikan teladan yang baik, sehingga proses penanaman karakter akan lebih efektif karena adanya figur yang dapat segera dicontoh dalam kehidupan seharihari.

c. Hendaknya meningkatkan kembali komunikasi dengan peserta didik, khususnya peserta didik yang tidak mukim di asrama pondok

\section{Peserta Didik}

a. Hendaknya lebih aktif dan semangat lagi untuk mengikuti segala kegiatan yang berperan dalam penanaman nilai-nilai karakter peserta didik.

b. Hendaknya dapat mendiskusikan antara materi umum dengan materi agama, sehingga terbentuk karakter yang tidak terbatas pada nilai-nilai agama saja.

c. Hendaknya menambah terus wawasan keilmuan yang tidak hanya terbatas pada penguasaan ilmu-ilmu agama saja.

\section{DAFTAR PUSTAKA}

Abd. Halim Soebahar, Kebijakan Pendidikan Islam dari Ordonansi Guru sampai UU Sisdiknas (Jakarta: PT. RajaGrafindo Persada, 2013)

Ali Imron, Manajemen Peserta Diddik Berbasis Sekolah (Jakarta: PT. Bumi Aksara, 2012)

E. Mulyasa, Manajemen Berbasis Sekolah, Konsep, Strategi, dan Implementasi (Bandung Remaja Rosdakarya, 2012

Lexy J. Moleong, Metode Penelitian Kualitatif (Bandung: Remaja Rosdakarya,2000)

Maragustam, Filsafat Pendidikan Islam Menuju Pembentukan Karakter Menghadapi Arus Global (Yogyakarta,Kurnia Kalam Seme sta.2014)

Nana Syaodih Sukmadinata, Metode Peneletian Pendidikan (Bandung: PT. Remaja Rosdakarya, 2012)

Purwanti, E. (2017). Implementasi Penggunaan SSP (Subject Specific Pedagogy) Tematik Integratif Untuk Menanamkan Tanggung Jawab, Kerja Keras, Dan Kejujuran. Terampil: Jurnal Pendidikan dan Pembelajaran Dasar, 3(2), 363-385.

Sugiyono, Metode Penelitian Pendidikan, Pendekatan Kuantitatif, Kualitatif dan $R \& D$ (Bandung: Alfabeta, 2009)

Sulistyorini, Manajemen Pendidikan Islam; Konsep, Strategi, dan Aplikasi (Yogyakarta: Sukses Offset, 2009)

Sutrisno Hadi, Metodologi Research 2 (Yogyakarta: Andi, 2004) 
Suharsimi Arikunto dan Lia Yuliana. 2008. Manajemen Pendidikan.Yogyakarta: Aditya Media Bekerja Sama dengan FIP Sumardi Sunyobroto, Metode Penelitian, (Jakarta: Raja Grafindo Persada, 1995)

Zubaedi, Desain Pembentukan Karakter Konsep, Dan Alikasinya Dalam Lembaga Pendidikan, (Jakarta: Kencana prenada media group,2011) 